\title{
AUDIT OPINIONS AND INFORMATION ASYMMETRY IN THE STOCK MARKET
}

DAVID ABAD, University of Alicante

JUAN PEDRO SÁNCHEZ-BALLESTA, University of Murcia

JOSÉ YAGÜE, University of Murcia

Acknowledgements: We thank an anonymous referee and the editor, Prof. Steven Cahan, for the helpful comments and suggestions received during the review process. We also appreciate comments from Roberto Pascual and workshop participants at the XXI Finance Forum, the 37th EAA Congress, and University of Alcalá. David Abad acknowledges financial support from the Ministerio de Ciencia y Competitividad through grants ECO2013-44409-P and ECO2014-58434-P. Juan Pedro Sánchez-Ballesta acknowledges financial support from Fundación Séneca (15358/PHCS/10). José Yagüe acknowledges financial support from Fundación Caja Murcia. 


\title{
Audit opinions and information asymmetry
}

\author{
in the stock market
}

\begin{abstract}
This paper analyzes the relationship between the content of the audit reports and information asymmetry levels in the stock market for a sample of Spanish firms. By implementing an association study, we document (1) that firms with audit qualifications show higher information asymmetry levels than those with unqualified opinions; (2) firms with non-quantified qualifications show higher informational asymmetry than firms with quantified qualifications; and (3) we find a stronger effect on informational asymmetry level in the case of going concern qualifications. Our findings suggest that audit qualifications reporting more uncertainty on firm accounting statements result in higher adverse selection risk.
\end{abstract}

Key Words: audit opinions, financial reporting quality, information asymmetry, adverse selection.

JEL codes: M42, G14, D82 


\title{
Audit opinions and information asymmetry
}

\author{
in the stock market
}

\section{Introduction}

The main objective of financial reporting is to provide useful financial information for decision-making concerning investment, credit, and other questions related to the allocation of resources (IASB, 2011). As a consequence, high quality accounting information is a pre-requisite for the correct-functioning of the capital markets and the economy and can be considered as a means of reducing information asymmetry and agency conflicts. To this end, since the accounting scandals of the early 2000s, researchers, practitioners, and regulators have focused considerable attention on financial reporting quality in general, and the role played by auditors in particular.

An important issue within this framework is the effectiveness of auditors and intermediaries who intervene in the process of assessing and communicating the reliability of financial information to enhance the credibility of financial reporting (Healy and Palepu, 2001). Effectively, because management is responsible for preparing financial reports, accounting users, such as market participants, expect an objective third party to provide assurance that the information reported is accurate. 
The audit report presents the auditor's opinion regarding whether a firm's financial statements conform to Generally Accepted Accounting Principles (GAAP). In other words, the external auditor assesses the validity and reliability of publicly reported financial information. In this sense, through a non-qualified audit report the auditors express that, in their opinion, all accounting standards have been properly observed by the company, thus enhancing the credibility of the financial statements. By contrast, a qualified audit opinion is the auditors' way of communicating with outside investors their concerns or reservations about the quality of the firm's financial statements or their inability to gather sufficient and appropriate information. Hence, the audit opinion is likely to affect the interpretation of financial information by stock market participants as it is through audit qualifications that auditors signal that earnings numbers generated by the firm are noisier or less credible than in unqualified reports (Choi and Jeter, 1992).

In this paper we focus on the effectiveness of audit reports to enhance the credibility of financial statements, and address a research question that has not yet been answered in the literature: whether audit qualifications and their different categories are associated with information asymmetry in the stock market. Since a qualified audit opinion may raise concerns about the reliability of the firm's financial information, and thus introduce noise in the assessment of the financial statements, we expect that those firms with qualified audit reports will show higher information asymmetry than those with unqualified 
opinions. Moreover, since audit qualifications are not homogeneous, as some appear to be potentially more significant than others, and some provide clearer information than others, we expect that the relation between audit opinions and information asymmetry depends on the different type of audit qualifications. Following the classification of qualified opinions proposed by Melumad and Ziv (1997) and Pucheta et al. (2004), we hypothesize that those qualified audit opinions -e.g. qualifications for asset realization, timing of revenue recognition, and GAAP compliance- that quantify their repercussions on the financial statements will be associated with less uncertainty, less disperse interpretations, and less information asymmetry than those qualifications that include unquantifiable uncertainties and going concern.

With regard to the consequences of auditing on information asymmetry, previous literature has examined the association of information asymmetry in the market with audit compensation (Ascioglu et al., 2005; Danielsen et al., 2007) and audit quality, proxied by $\operatorname{Big} n$ and industry specialists auditors (Clinch et al., 2012). The main findings obtained are that higher audit compensation is associated with greater adverse selection and lower liquidity in the market, while higher quality auditors enhance the credibility of the information reported by companies and thus reduce the level of information asymmetry among investors. A related stream of literature on the information content of audit opinions has analyzed the stock price reaction when the qualified audit opinion is disclosed. Here, the evidence is mixed (e.g. Dodd et 
al., 1984; Dopuch et al., 1986; Chen et al., 2000; Pucheta et al., 2004) and can be attributed to the typical limitations of short-run event study methodology (Choi and Jeter, 1992, Soltani, 2000). Taking a different approach, Choi and Jeter (1992) extend the studies on market reaction to audit qualifications by analyzing their effect on the earnings response coefficient, and find that the issue of qualified audit reports is followed by a reduction in the earnings response coefficient. However, the authors are unable to discern whether the decrease in the market's responsiveness to earnings is motivated by the signal conveyed to the market by audit opinions about the level of uncertainty in the firm's earnings numbers, or because the audit opinion reflects the underlying economic situation of the firm.

More recent research has analyzed the stock market reaction to a specific type of audit qualification, that of the going concern opinion, by using the long-run event study methodology (e.g. Taffler et al., 2004; Ogneva and Subramayam, 2007; Kausar et al., 2009) or by examining firms' financial statement components for assessing share price valuation (Blay et al., 2011). This literature concludes that the going concern opinion is a valuable risk communication to the equity market. There is also a current line of research focusing on the consequences of audit opinions in the debt market (Niemi and Sundgren, 2012; Chen et al., 2014). Nevertheless, our study is, to the best of our knowledge, the first to examine whether the information contained in the final output of the auditing process has economic consequences in terms of 
information asymmetry in the stock market. In doing this, we also try to isolate the effect of the audit qualification on information asymmetry in the market by controlling for endogeneity and the other underlying economic or financial reporting characteristics of the firms.

We test our hypotheses in a sample of Spanish non-financial firms in the period 2001-2008. Auditing of the annual financial statements by independent auditors has been compulsory for all Spanish listed companies since the implementation of the Spanish Audit Act (Ley de Auditoría) in 1990. Spain is a code law country where the litigation risk against auditors is low, but the reforms introduced by the Financial Act in 2002 have led to an increase in audit quality (De las Heras et al., 2012). This reform was introduced with the aim of enhancing auditor independence and competence by imposing quality controls under the supervision of the Institute of Accounting and Auditing (ICAC) along with stricter disciplinary sanctions. With respect to the content of the audit report, in Spain the audit report refers to the complete financial statements; thus it is not permitted to have an unqualified opinion on one of the financial statements and a qualified or adverse opinion or disclaimer on another. Moreover, audit reports for Spanish firms show high variability in audit qualifications, which makes the Spanish case a suitable context for examining the association between the different categories of audit qualifications and information asymmetry. 
We compute various market microstructure proxies for information asymmetry using high frequency data: the relative spread, intraday price impact, the probability of informed trading $(P I N)$, and an index of information asymmetry as the first principal component of the three former measures. According to our hypotheses, we find that firms with qualified audit opinions show higher adverse selection risk in the market. Our findings also indicate that the association between audit qualifications and information asymmetry is motivated by qualifications including unquantifiable uncertainties and goingconcern given that we cannot find a significant association between quantifiable qualifications and information asymmetry. These findings suggest that the information included in quantified qualifications can be used by market participants to unanimously adjust the earnings and equity numbers of the firm. Finally, within the non-quantified audit opinions, we find that the category of going concern appears to have a stronger relation with the level of informational asymmetry in the market.

An alternative explanation for our results could be that economic characteristics of the firms, such as their financial situation or earnings management, lead to information asymmetry and qualified audit opinions simply reflect this fact (Choi and Jeter, 1992). In order to clarify whether the audit opinion creates or merely reveals information asymmetry caused by other variables, or even if our findings are conditioned by endogeneity between information asymmetry and audit opinions, we carry out several robustness 
tests. Thus, we control for the financial situation of the firm and earnings management in order to rule out the possibility that these variables are causing the association between audit opinions and information asymmetry. We also address the possible endogeneity between the audit opinion and information asymmetry, i.e., information asymmetry may cause audit opinions, by running a two-stage estimation procedure where, in the first stage, the probability of qualified audit opinions is obtained through a probit model that includes information asymmetry as an explanatory variable. The results indicate that the firm's financial situation (earnings management) is negatively (positively) associated with the probability of issuing a qualified audit opinion, but we do not find a significant effect of information asymmetry on this probability. Besides, the estimates in the second stage including the probability of audit opinions as an independent variable confirm our previous results. All these findings support our hypothesis that it is the audit opinion which causes information asymmetry in the market.

This paper contributes to the literature on microstructure and the economic consequences of financial reporting by showing that the content of the audit report affects the credibility of firm's financial statements, and that the market is able to interpret each type of qualification differently. Our findings are consistent with related research on the market effects of disclosure and earnings quality (Diamond and Verrecchia, 1991; Easley and O'Hara, 2004; Lambert et al., $2007 \& 2012$ ) and with research that examines the effect of 
audit opinions on contracting (Chen et al., 2014) by confirming that adverse audit opinions have relevant economic value for markets participants. This paper also extends previous research on the economic consequences of earnings quality (Dechow et al., 2010) suggesting that audit qualifications, as an external indicator of financial reporting quality, have market effects among traders. These results may be of interest to those wishing to understand the market effect of the credibility of financial information and, in particular, for academic researchers, investors, managers, regulators, and institutions related to the auditing profession.

The rest of the paper proceeds as follows. Section 2 reviews the related literature on audit opinions and information asymmetry and develops our testable hypotheses. Section 3 describes the research design in detail, with the model, the description of the different variables and the sample. Section 4 shows the results and the final section presents the main conclusions of the paper.

\section{Related literature and hypotheses}

Previous theoretical research has shown that more and better firm disclosure reduces information asymmetry between the firm and its stakeholders or among traders in the stock market. Higher disclosure quality should reduce information asymmetry by reducing private information search incentives 
(Diamond, 1985; Diamond and Verrecchia, 1991; Easley and O'Hara, 2004), and the relative amount of informed trading (Fishman and Hagerty, 1989; Merton, 1987). Since information asymmetries create costs by introducing adverse selection into transactions between buyers and sellers (Leuz and Verrecchia, 2000), the reduction of the advantage of informed investors reduces the risk of adverse selection and improves the level of liquidity for firm shares (Kyle, 1985; Glosten and Milgrom, 1985).

Prior empirical research has analyzed the relation between information asymmetry among market participants and disclosure and earnings quality. Regarding disclosure, empirical studies employ overall disclosure quality scores calculated by different analysts' associations such as the Association of Investment Management and Research (AIMR) or the Financial Analysts Federation (FAF). The evidence shows that higher quality disclosure is negatively associated with effective bid-ask spreads (Welker, 1995; Healy et al., 1999), adverse selection spread components (Heflin et al., 2005), and the average level of information asymmetry measured by PIN (Brown and Hillegeist, 2007). From an earnings quality perspective, Bhattacharya et al. (2013) find that higher reporting quality, proxy by measures of accrual-based earnings management, leads to higher liquidity and lower trading costs.

Our study differs from this stream of literature in that it is focused on the role played by the audit report in enhancing the credibility of financial information reported by firms. Financial information may reduce investors' assessed 
information risk in the market if investors perceive financial information to be credible (Hope et al., 2011). In this sense, auditors contribute to assess the reliability of financial information, with the audit opinion representing a crucial piece of information for financial statement users (Butler et al., 2004). Accordingly, since a qualified audit opinion manifests concerns about the reliability of the firm's financial information, it increases the uncertainty about the precision of accounting figures and thus, augments the information risk in the assessment of financial statements by market participants.

Despite the importance of the audit opinion in evaluating the quality of accounting information, there is little evidence regarding the relevance of the audit report conclusions in stock markets. Basically, the majority of prior studies have focused on whether the audit report release brings new information to the market by studying the market reaction to qualified audit opinions on the days around the announcement. These studies provide ambiguous evidence that may be attributed to problems in research design: data selection and methodological issues such as the difficulty to clearly determine the correct event date, the measurement of the unanticipated component of the announcement, and the potentially confounding effects of simultaneous news releases (Choi and Jeter, 1992; Soltani, 2000). On the one hand, studies such as Firth (1978), Dodd et al. (1984), and Pucheta et al. (2004) show that qualified opinions do not provide investors with new information, in part because they can be anticipated. On the other hand, other studies such as Dopuch et al. 
(1986), Chen et al. (2000), and Soltani (2000), report significant negative price revisions to qualified audit reports, suggesting that qualified audit opinions convey adverse information to the market. Choi and Jeter (1992) examine another insight into the capital market effects of audit opinions and, for a sample of 'subject to' and consistency qualifications, find a reduction in the earnings response coefficient after the issuances of qualified audit opinions. According to Choi and Jeter (1992), this finding is consistent with two alternative explanations: The first one is that audit qualifications signal to the market that earnings numbers provided by the firm are more uncertain or less persistent than expected. The second interpretation is that audit qualifications may reflect underlying changes in the economic conditions of firms and these changes, rather than the qualification itself, cause the decline in the earnings response coefficient.

We hypothesize that qualified audit opinions affect the investors' perception of earnings uncertainty or quality, but our study differs from previous research in that we are not interested in the reaction of stock prices around the date of the audit report announcement. We examine how audit opinions are related to the average level of information asymmetry among market participants. Therefore, we examine the audit opinion-information asymmetry relation in an association study context. In this sense, a branch of literature which is more related to our study design is one which analyzes the effect of audit opinions on contracting 
in the private debt market (Chen et al.., 2014; Neimi and Sundgren, 2012). ${ }^{1}$ Moreover, this type of analysis will help both to ascertain whether audit opinions provide the market with useful information, avoiding the weaknesses of traditional event studies, and to look deeper into the directional association between audit qualification opinions and information asymmetry.

Our first hypothesis can be stated as follows:

H1: Firms with qualified audit reports will show higher information asymmetry in the stock market than those with unqualified opinions.

Audit qualifications can be of different types and it is expected that their market effects depend on the information conveyed in the audit report to investors. Following classifications used in previous research (Melumad and Ziv, 1997; Pucheta et al., 2004), we group audit qualifications into those that quantify their repercussions on financial statements- e.g. qualifications for asset realization, timing of revenue recognition, and GAAP compliance- and those that cannot be quantified -uncertainties and scope limitations, and going concern. We analyze whether either category of qualification reveals differences in information asymmetry in the market when compared to unqualified opinions. We expect that those qualifications that involve higher uncertainty and which, as a consequence, are less easily adjusted by market

\footnotetext{
${ }^{1}$ Consistent with the monitoring role of audit opinion on accounting quality, Chen et al (2014) find that a qualified audit opinion is associated with increases in the interest rate of loans, lower loan sizes, and a higher likelihood of collateral requirement. On the other hand, Niemi and Sundgren (2012) do not find, for a sample of small and medium sized firms, that audit qualifications affect credit availability from institutional lenders.
} 
participants, will be associated with higher information asymmetry than those that are easily adjusted. So our second hypothesis is the following:

$\mathrm{H} 2$ : Firms with non-quantified audit qualifications will show higher information asymmetry in the stock market than those with quantified qualifications.

Finally and focusing on non-quantified qualifications, we consider going concern opinions as a kind of more sensitive and significant information that could generate more controversial opinions and interpretations in the market. Going concern audit reports are disclosed by auditors with substantial doubts about the ability of the audited firm to continue to exist. On the contrary, uncertainties and scope limitations qualifications are released when the auditor shows disagreement to specific aspects of the financial statements but it is not possible to quantify their effects or they cannot be thoroughly examined because of various problems in carrying out the auditing task. Therefore, we expect going concern qualifications to have stronger effects on informational asymmetries in the market than those regarding uncertainties and scope limitations

H3: Firms with non-quantified qualifications regarding going concerns will show higher information asymmetry in the stock market than those with nonquantified qualifications concerning uncertainties and scope limitations. 


\section{Research design}

\subsection{Model specification}

To examine the association between the audit opinion and different proxies for information asymmetry, we use the following regression model:

$$
\begin{gathered}
A S Y_{i, t}=\beta_{0}+\beta_{1} Q_{A} A O_{i, t-1}+\beta_{2} \text { Size }_{i, t}+\beta_{3} \text { Turnover }_{i, t}+\beta_{4} \text { Volat }_{i, t}+ \\
+\beta_{5} \text { BigN }_{i, t-1}+\beta_{6} \text { Zscore }_{i, t}+\sum_{t} \beta_{t} \text { Year }+\sum_{j} \beta_{j} \text { Ind }+\varepsilon_{i, t}
\end{gathered}
$$

where $A S Y$ is one of our four proxies for information asymmetry and $Q A O$ corresponds to the different types of qualified audit opinions. Both variables are discussed in detail in the next two subsections. $Q A O$ is lagged by one year relative to $A S Y$ because the audit report released each year refers to annual financial statements for the previous one. As control variables we include Size, Turnover, Volat, BigN, and Zscore. The microstructure literature shows that firm size, trading volume, and stock volatility are important determinants of stock liquidity and the information asymmetry level. In particular, prior studies provide empirical evidence of big, frequently traded and less volatile firms being more liquid and suffering lower information asymmetry problems (e.g. Easley et al., 1996; Stoll, 2000). Size is measured as the logarithm of the total assets at the end of the fiscal year. Turnover is the logarithm of the average daily trading volume in euros scaled by the market value of the firm's equity at the end of the year. Volat is a proxy for stock return volatility calculated as the daily squared close-to-open mid-quote return. We expect $\beta_{2}<0, \beta_{3}<0$, and 
$\beta_{4}>0$. The variable $B i g N$ is a proxy for audit quality, which takes value 1 if the firm is audited by a Big $n$ auditor and 0 otherwise. Clinch et al. (2012) find that employing a Big $n$ auditor is associated with lower information asymmetry between traders $\left(\beta_{5}<0\right.$ is expected). Zscore represents firms' financial strength measured with the re-estimated Altman Z-score by Begley et al. (1996):

$$
\begin{aligned}
& \text { Zscore }= \\
& =\frac{0.106 E B I T+0.169 \text { Sales }+1.01 \text { RE }+0.104 W C}{\text { Total Assets }}+\frac{0.003 \text { Market Value Equity }}{\text { Book Value Debt }}
\end{aligned}
$$

where $E B I T$ is earnings before interest and taxes, $R E$ retained earnings, and $W C$ working capital. Prior research shows that financial distress is associated with the probability of receiving an audit qualification (e.g. Hudaib and Cooke, 2005). This is particularly relevant in the case of going concern audit opinions, because this type of audit qualification is issued for firms approaching bankruptcy or that show increasing signs of financial distress (Blay et al., 2011). Finally, to control for temporal and industrial effects, we include year and industry dummy variables.

In order to investigate further into the directional association between the audit opinion and information asymmetry and thus consider the possible endogenous relation between them, we also employ a two-stage probit approach (Brown and Hillegeist, 2007). It is possible that firms with high information asymmetry among investors may be more likely to receive an audit qualification or that firm characteristics may simultaneously affect information asymmetry and 
qualified audit opinions. ${ }^{2}$ In the first stage, we use the following probit estimation of the probability of receiving an audit qualification:

$$
\begin{aligned}
& P(Q A O)_{i, t}=\beta_{0}+\beta_{1} \text { Size }_{i, t}+\beta_{2} \text { BigN }_{i, t}+\beta_{3} \text { Zscore }_{i, t}+ \\
& +\beta_{4} \text { DiscAcc }_{i, t}+\beta_{5} A S Y_{i, t}+\sum_{t} \beta_{t} \text { Year }+\sum_{j} \beta_{j} \text { Ind }+\varepsilon_{i, t}
\end{aligned}
$$

where DiscAcc is the the absolute value of discretionary accruals estimated by the Jones (1991) model modified by Dechow et al. (1995) and the rest of variables have been defined previously. Prior research on the determinants of audit qualifications includes firm size, auditor size, and proxies for financial situation as explanatory variables of the probability of issuing a modified audit report (e.g. Dopuch et al., 1987; Ireland, 2003). We also include DiscAcc, a proxy for earnings management, since prior studies suggest that high discretionary accruals are associated with audit qualifications (e.g. Bartov et $a l ., 2000)$. In the second stage, we include the fitted probability from the firststage as an explanatory variable for the information asymmetry model.

$$
\begin{gathered}
A S Y_{i, t}=\beta_{0}+\beta_{1} \operatorname{Est}(Q A O)_{i, t-1}+\beta_{2} \text { Size }_{i, t}+\beta_{3} \text { Turnover }_{i, t}+ \\
+\beta_{4} \text { Volat }_{i, t}+\beta_{5} \text { BigN }_{i, t-1}+\beta_{6} \text { Zscore }_{i, t}+\sum_{t} \beta_{t} \text { Year }+\sum_{j} \beta_{j} \text { Ind }+\varepsilon_{i, t}
\end{gathered}
$$

where $\operatorname{Est}(Q A O)$ is the fitted probability of receiving an audit qualification and the rest of the variables have been defined previously.

\footnotetext{
${ }^{2} \mathrm{We}$ want to thank the anonymous referee and the editor for their comments regarding this point.
} 


\subsection{Proxies for information asymmetry}

Market microstructure literature has proposed various measures and procedures to capture financial market perception on the adverse selection that exists between informed and uninformed traders. In contrast to the measures introduced by corporate finance, market microstructure exploits several sources of information contained in intraday data to capture the presence of traders with better information. The first and effortless measure of asymmetric information is the bid-ask spread, a widely used measure of trading costs (liquidity). Bid-ask spread incorporates a component related to the protection that liquidity providers demand for being adversely selected. Glosten and Milgrom (1985) and Easley and O'Hara (1992) theoretically show that the mere presence of traders with different levels of information is enough to explain the existence of the bid-ask spread. However, bid-ask spread is a noisy measure of asymmetric information due to the fact that it commonly includes components other than information (inventory costs, order processing costs or monopoly rents, among others). In our analysis, we compute the relative effective spread (RES) as follows: ${ }^{3}$

$$
R E S_{t}=\frac{2 *\left|p_{t}-Q_{t}\right|}{Q_{t}}
$$

\footnotetext{
${ }^{3}$ In contrast with US markets, trading is not allowed inside the best quotes in the Spanish (order-driven) market. However, RES computation is meaningful since by using the marginal price, we incorporate the role played by aggressive orders in the analysis (see Biais et al, 1995).
} 
where $p_{t}$ is the marginal price of trade $t . Q_{t}=\left(a_{t}+b_{t}\right) / 2$ is the quoted midpoint in $t$, commonly used as a proxy for the efficient price; $a_{t}$ and $b_{t}$ corresponds to the ask and the bid quotes in $t$. This measure is computed first on a daily basis by averaging all the observations within the day. Bid-ask spread observations are recorded in trade-time and then, a volume-weighted average is computed. After that, a yearly observation is obtained by averaging (equally-weighted) all the days within the year.

Huang and Stoll (1996) introduce the realized spread and the price impact by considering the quote adjustment that takes place a period of time after a trade to extract the presence of new information. Price impact $(P I)$ is our second approach to asymmetric information and is defined as follows:

$$
P I_{t+\tau}=\left(Q_{t+\tau}-Q_{t}\right) X_{t}
$$

where $Q_{t}$ is the quote midpoint defined previously, $X_{t}$ is a trade indicator variable taking the value -1 if the trade in $t$ is initiated on the sell side and 1 if it is initiated on the buy side. Finally, $\tau$ is the period of time for prices to fully reflect the information content in trade $t$. Following Huang and Stoll (1996) we used periods of 5 and 30 minutes. ${ }^{4}$ Similar to the relative effective spread $(R E S)$, Price Impact $(P I)$ is also computed in trade-time by averaging (volume-

\footnotetext{
${ }^{4} \mathrm{We}$ only report here the results using the 30-minute price impact. The results using the 5minute price impact are quite similar to those presented and they are available upon request from the authors.
} 
weighted) all the trades within the day and after that, by averaging (equally weighted) all the trading days within the year.

As a third measure of information asymmetry, we compute the probability of information-based trading (PIN), a measure that can be included into the group of the asymmetric information measures based on the computation of order imbalances between buys and sells to extract the information content of the trading process. PIN is a well-known measure based on the theoretical work of Easley and O'Hara $(1987,1992)$, although the original PIN model was introduced by Easley et al. (1996). The PIN is the unconditional probability that a randomly selected trade originates from an informed trader. This measure is not directly observable but a function of the theoretical parameters of a microstructure model that have to be estimated by numerical maximization of a likelihood function. Once the parameters of interest are estimated, PIN is calculated as:

$$
P I N=\frac{\alpha \mu}{\alpha \mu+\varepsilon_{b}+\varepsilon_{s}}
$$

where $\alpha$ is the probability of an information event occurs between trading days, $\mu$ is the arrival rate of orders from the informed traders, and $\varepsilon_{b}$ and $\varepsilon_{s}$ are the arrival rate of buy and sell orders from uniformed traders, respectively. Thus, the PIN is the ratio of orders from informed traders to the total number of orders. 
We estimate first the PIN model via maximum likelihood for each stock and month in each year. Easley et al. (1997) indicate that a 30 trading-day window allows sufficient trade observations for the PIN estimation procedure. Akay et al. (2012) use 20 trading days to estimate PIN finding numerical solutions for all their estimations. Hence, the use of one-month transaction data should be wide enough to produce reliable estimates. ${ }^{5}$ Once monthly PIN estimations are obtained, and if we get at least six valid values, an annual PIN is calculated by averaging monthly values.

Finally, to isolate the common adverse selection component underlying the prior three proxies we aggregate them into a single information asymmetry factor (ASYf) by employing principal components analysis. The first (and only) factor with an eigenvalue greater than one explains $78.8 \%$ of the variance and each component of the asymmetry factor enters with positive sign and similar weight, leading to the following $A S Y f$ measure, which is used as our fourth information asymmetry proxy:

$$
A S Y f_{i t}=0.405 R E S_{i t}+0.396 P I_{i t}+0.320 P I N_{i t}
$$

\footnotetext{
${ }^{5}$ We use the optimization algorithm of the Matlab software. We run the maximum likelihood function 100 times for each stock in our sample, except for several large stocks, for which we increase the iterations to 1000 to ensure that a maximum is reached. We follow Yan and Zhang (2012) proposal to set initial values for the five parameters in the likelihood function.
} 


\subsection{Audit Opinions variables}

To test our three hypotheses on the relationship between audit opinions and information asymmetry in the stock market, we use dummy variables for the different audit reports categories.

To test our first hypothesis about clean audit reports leading to lower information asymmetry than qualified reports, we define $Q A O$ as a dummy variable that takes the value 1 in the case of a qualified opinion, and zero in the case of an unqualified opinion. Since we predict that qualified audit reports generate more information asymmetry, we expect $\beta_{1}>0$ in model (1).

To test our second hypothesis about the relationship between information asymmetry and the type of information contained in the auditor qualifications, we follow the approaches of Melumad and Ziv (1997) and Pucheta et al. (2004) and identify two types of qualified opinion: quantified and nonquantified. In the case of quantified qualifications the auditor not only issues a qualified audit report but also quantifies the extent of asset overstatement and/or liability non-recognition or nondisclosure that cause the qualification. These qualifications generally arise from material errors or instances of noncompliance with accounting standards, or from significant changes in the accounting principles and standards applied by the company. Non-quantified qualifications include those for future financing, going concern, scope limitations and uncertainties that cannot be objectively quantified. In these cases, the auditors cannot estimate the effect of their qualifications on financial 
statements. Based on this classification of audit qualifications, we define two dummy variables:

- Quantified is a dummy variable that takes the value 1 in the case of quantified audit reports, and zero in the case of unqualified audit reports.

- Non-quantified is a dummy variable that takes the value 1 in the case of non-quantified audit opinions (going concern, scope limitations and uncertainties), and zero in the case of unqualified audit opinions.

With Non-quantified and Quantified proxies we test whether the level of information asymmetry in the stock market depends on the quantified information contained in the audit report. In this sense, we expect a higher level of information asymmetry in the stock market for those firms with nonquantified audit reports. Non-quantified reports can be considered as less objective and/or containing more ambiguous information that may lead to confusing interpretations among financial statements users thereby increasing informational asymmetries.

Finally, we will also analyse the market effect of both types of non-quantified reports, going concern on one side, and uncertainties and scope limitations on the other. We expect going concern reports to contain more sensitive information which may provoke a higher level of adverse selection in the 
market. For this, we use the third and fourth proxies of audit opinions to test our third hypothesis:

- Gconcern, a dummy variable that takes the value 1 in the case of a going concern audit report, and zero in the case of unqualified audit opinions;

- Uncertainties, a dummy variable that takes the value 1 in the case of uncertainties and scope limitations, and zero in the case of unqualified audit opinions.

\subsection{Market description, data, and sample}

Our sample is made up of stocks traded on the electronic trading platform of the Spanish Stock Exchange, known as the SIBE (Sistema de Interconexión Bursátil Español). The SIBE is an order-driven market where liquidity is provided by an open limit order book. Trading is continuous from 9:00 a.m. to 5:30 p.m. There are two regular call auctions each day: the first one determines the opening price (8:30-9:00 a.m.), while the second one sets the official closing price (5:30-5:35 p.m.). Three basic types of orders are allowed: limit orders, market orders, and market-to-limit orders. In the continuous session, a trade occurs whenever an incoming order matches one or more orders on the opposite side of the limit order book. Submitted orders that are not instantaneously executed are stored in the book waiting for a counterparty according to a price-time priority rule. Unexecuted orders can always be cancelled and modified. Continuous trading could be temporarily interrupted 
by a system of stock-specific intraday price limits and short-lived call auctions that is implemented to handle unusual volatility levels. In all auctions (open, close and volatility) orders can be submitted, modified or cancelled, but no trades occur.

Trade and quote data for this study come from SM data files provided by Sociedad de Bolsas, S.A. SM files comprise detailed time-stamped information about the first level of the limit order book for each stock listed on the SIBE. Any trade, order submission or cancellation affecting best prices in the book generate a new record. The distinction between buyer-initiated and sellerinitiated trades is straightforward, without the need to use a classification algorithm. The audit opinion data were taken from the Spanish Securities Market Commission (CNMV), and the firms' financial statement data were obtained from the SABI database, made by Bureau Van Dijk.

The initial sample consists of all non-financial firms listed on the main segment of the SIBE in the period 2001-2008. After applying the usual filters to detect and eliminate errors in the preparation of the intraday trading data and the financial data, we consider those firm-year observations for which we have been able to collect the type of audit opinions, the information asymmetry measures and the control variables. The final sample consists of 103 firms and 562 firm-year observations. 
Table 1 reports descriptive statistics for the variables of our sample. Panel A reports the mean value, the standard deviation and the percentiles $10 \%, 50 \%$ and $90 \%$ for continuous variables. The mean (median) of relative effective bidask spread $(R E S)$ is $0.66 \%(0.44 \%)$. The average (median) of price impact measure $(P I)$ is $0.38 \%(0.30 \%)$. As expected PI shows lower values than RES since $P I$ is a less noisy measure of information asymmetry than RES. The probability of informed trade (PIN) shows a mean (median) value around 19\% (18\%). These PIN values are consistent with those reported in prior studies that use this information asymmetry proxy (e.g. Brown and Hillegeist, 2007). The statistical distributions of the above measures show that there are clear differences in the degree of asymmetric information among the firms included in our sample. Finally, market control variables (size, turnover, and volatility) show a significant level of dispersion in their values reflecting the heterogeneity of our firm-year sample. Panel B shows the frequencies of dummy variables for audit opinions: $12.63 \%$ of the audit report observations present qualifications whereas $87.37 \%$ are unqualified. Qualifications are distributed into uncertainties and scope limitations (46.48\%), going concern $(26.76 \%)$ and quantified (26.76\%). Most of the audit reports are issued by Big $N$ auditors $(94.13 \%)$.

\section{-INSERT TABLE 1-}

Table 2 reports different statistics regarding audit opinions in our sample. Panel A shows the distribution of audit qualifications per firm-year. For the general 
category, $Q A O$, and for each specific category two columns are reported: the first column indicates the number of firms receiving a certain number of qualifications in our eight-year sample period (from a minimum of 1 to a maximum of 8) and the second column shows the total number of qualifications. Thus, according to these values, there are 19 firms that receive only one qualification in the period 2001-2008, 7 firms receive two qualifications, and only 1 firm obtains qualifications every year. The average number of qualifications obtained by those firms that receive at least one qualification is 2.09. For the different categories of audit opinions, the distribution of firm-year observations is similar. Therefore, this distribution of qualifications in the sample rules out the possibility that the results of our analysis could be driven by a few firms with repeated qualifications. Panel B displays the descriptive statistics of the magnitude of quantified opinions, where Quantification is the income effect of quantified opinions over total assets and Abs_Quantification is the absolute value of Quantification. We observe that 16 quantified opinions imply a reduction of firm's earnings by the auditors (negative values) whereas only 3 quantified opinions involve corrected earnings higher than those reported (positive values). Moreover, in absolute terms, the negative corrections are higher than the positive ones. This means that firms tend to deviate from GAAP to overstate their earnings, and that auditors reduce these numbers by issuing a quantified audit opinion. The nature of these quantified opinions is diverse. Bearing in mind that in several firmyear observations there may be more than one cause for issuing an audit report 
with a quantified qualification, the most frequent discrepancies reported are the following: goodwill amortization with reserves instead of expenses (8 cases); fiscal aspects, i.e. change of criterion in the accounting of tax deductions, adjustment of fiscal assets and liabilities because of a tax rate change, or incorrectly recorded recoverable taxes (4); discrepancies related to adjustments of the book value of assets (4); goodwill amortization in excess or provision surplus (3); and incorrectly recorded outstanding expenses (3). Finally, Panel C shows that the distribution of audit opinions by type of auditor is quite similar.

\section{-INSERT TABLE 2-}

Table 3 provides the Pearson correlation matrix between our continuous variables. All the information asymmetry proxies report positive and significant correlations between them, with values above $90 \%$ between RES and PI, and around 58\% (51\%) between PIN and RES (PI). Moreover, they show higher correlations with ASYf $(96 \%, 94 \%$, and $76 \%$ with RES, PI, and PIN, respectively). The correlations between information asymmetry proxies and control variables are significant and they present the expected signs according to previous literature (with the exception of volatility with PIN, which is not significant).

- INSERT TABLE 3- 


\section{Results}

The empirical section starts with a univariate analysis of the relation between audit opinions and information asymmetry. We examine whether there is a significant difference in the level of information asymmetry between firms with clean audit reports and firms with qualified audit reports. Panel A of Table 4 presents mean values for our proxies for information asymmetry in both groups, as well as $t$-test and Mann-Whitney test (z-statistic) values to check the null hypothesis of no significant differences between both types of audit reports. The univariate analysis confirms that audit qualifications are associated with higher levels of information asymmetry. We also test whether there is a significant difference or not in the level of information asymmetry between firms audited by a Big $n$ auditor. The results presented in Panel B of Table 4 suggest that audit reports issued by $\operatorname{Big} n$ auditors are associated with lower levels of information asymmetry in the market.

\section{- INSERT TABLE 4-}

After the preliminary analysis, we evaluate the relation between audit opinions and information asymmetry through four OLS regressions with clustered standard errors at the firm level and controlling for other variables as described in Model (1). Table 5 reports the results for the different information asymmetry proxies used as dependent variables. Consistent with our first hypothesis, we find that the coefficient on $Q A O$ is positive and statistically 
significant (5\% level) in three out of four regressions, suggesting that qualified audit reports are significantly associated with higher levels of information asymmetry once we control for other variables. In addition, the signs of the coefficients on control variables are as expected according to prior literature and all of them, except in the PIN regression, are statistically significant. We also find, as shown in the univariate analysis, that those reports issued by $\operatorname{Big} n$ auditors present significantly lower information asymmetry (10\% level), with the exception of the PIN regression.

\section{- INSERT TABLE 5-}

Since our results show that audit qualifications are associated with a higher level of information asymmetry, our next step is to test whether this relationship depends on the type of qualified opinion issued by the auditor. Table 6 reports the estimated coefficients for the regression of the composite index of information asymmetry $(A S Y f)$ on each of type of qualified opinion and control variables. ${ }^{6}$ According to our second hypothesis, we expect that firms with non-quantified qualifications (going concern, uncertainties and scope limitations) present higher levels of information asymmetry than those with quantified qualifications in their audit reports. Columns (1) and (2) report

\footnotetext{
${ }^{6}$ The results for $\mathrm{H} 2$ and $\mathrm{H} 3$ are reported exclusively using the composite index of asymmetric information $(A S Y f)$. The results using the other three measures are qualitatively quite similar to those reported. Regarding $\mathrm{H} 2$, quantified qualifications do not show significant associations with RES, $P I$, and PIN, whereas non-quantified qualifications are significantly associated with each of these measures. With regard to $\mathrm{H} 3$, when we split non-quantified qualifications into going concern and uncertainties, we find a significant association of going concern and uncertainties with RES and PI, but not with PIN at conventional levels. All results are available upon request from the authors.
} 
the OLS regressions for ASYf on Quantified and Non-quantified audit qualifications, respectively. We observe that the coefficient on Non-quantified audit qualifications is positive and significant (at the $1 \%$ level), which means that non-quantified audit reports generate more information asymmetry than unqualified reports. Nevertheless, the coefficient on Quantified audit qualifications, although positive, is not statistically significant. These findings suggest that when the auditor provides precise information about the quantitative impact of the qualifications on earnings, this kind of information causes fewer heterogeneous interpretations, thus avoiding the possible exacerbation of information asymmetry problems in the stock market. As was shown in Table 5, control variables behaviour is consistent with previous literature.

\section{- INSERT TABLE 6 -}

Once we have found that non-quantified audit qualifications are positively and significantly associated with adverse selection risk in the market, we further examine whether this relationship depends on the kind of information disclosed by non-quantified qualifications. Thus, non-quantified qualifications are subdivided into two categories: going concern, and uncertainties and scope limitations. Column (3) of Table 6 shows the regression results for going concern qualifications whereas Column (4) reports the regression results for uncertainties and scope limitations. In the case of going concern reports, we find a positive and significant association with ASYf at the $1 \%$ level, whereas in 
the case of uncertainties and scope limitations the coefficient is also positive and significant at the 5\% level. However, the effect is clearly stronger for going concern opinions, whose coefficient on information asymmetry is around four times higher than that obtained in the other category. Therefore, we can assert that both categories are related with higher levels of adverse selection in the market once we control for other variables, but the effect is stronger for those opinions related to a higher uncertainty about the viability of the firm (going concern), which is consistent with our third hypothesis.

Prior research finds that discretionary accruals are associated with higher information asymmetry (Bhattacharya et al., 2013). Thus, we include as an additional control variable in our regressions the absolute value of discretionary accruals -estimated with the modified version by Dechow et al. (1995) of the Jones (1991) model- in order to assess whether the information contained in the audit report impacts on information asymmetry in the market beyond the effect of earnings management. In Table 7 we display the main analyses by controlling for discretionary accruals and the results regarding the effect of qualified audit opinions on information asymmetry remain unchanged. Accordingly, we rule out the possibility that the variable which is causing information asymmetry is earnings management instead of the audit opinion. Moreover, we do not find a significant association between discretionary accruals and information asymmetry in the Spanish stock market.

\section{- INSERT TABLE 7-}


In the descriptive analysis we have shown that the distribution of audit opinions by Big $n$ and non-Big $n$ auditors is quite similar. Nevertheless, as other additional robustness test of the results reported, we assess whether the type of auditor influences the results obtained. Thus, in Table 8 we repeat the previous analyses excluding audit reports issued by non Big $n$ auditors, and the results remain unchanged.

\section{- INSERT TABLE 8-}

Table 9 reports the results of the two-stage probit approach implemented to address the potential endogeneity concerns between audit opinions and information asymmetry. Columns (1) and (2) present the probit estimation of Model (3), considering the entire sample and only the audit reports issued by Big $n$ auditors, respectively. We find that bigger and healthier firms show less probability of receiving qualified opinions, whereas firms with higher earnings management are more likely to receive a qualified report. On the other hand, the results in Column (1) show that the type of auditor is not significantly related to the probability of receiving an audit qualification. Besides, information asymmetry is not significantly associated with the probability of receiving a qualified opinion, so we reject the hypothesis that firms with high information asymmetry are more likely to receive a qualified opinion. Columns (3) and (4) present the results of the second stage for the entire sample and for the sample of Big $n$ auditors, respectively. We find that the coefficient on the fitted probability from the first-stage probit model, Est $(Q A O)$, is positive and 
significant at the $1 \%$ level in both samples, and the signs and significance of the control variables are similar to those reported in previous analyses. This finding supports our hypothesis that qualified audit opinions create information asymmetry in the market after controlling for the possible endogenous relation between the audit opinion and information asymmetry.

\section{- INSERT TABLE 9-}

\section{Conclusions}

This paper analyzes the role of the audit report in enhancing the credibility of financial information in the stock market. Although previous studies have examined the association between information asymmetry and the financial reporting process through disclosure, earnings quality, and different proxies of audit quality, there is a gap in the literature with regard to the association between audit qualifications and information asymmetry. We provide the first evidence on this issue for a sample of Spanish listed firms during the period 2001-2008.

We use several microstructure measures of information asymmetry: the relative spread, intraday price impact, PIN, and a combined factor of the previous three measures, and find that firms with audit qualifications show higher information asymmetry than those with unqualified opinions. In a subsequent analysis we investigate the relation between the type of audit qualification and information asymmetry, and find that firms with non-quantified qualifications show higher 
information asymmetry than firms with unqualified opinions. In contrast, there is no significant difference between quantified qualifications and unqualified opinions in relation to information asymmetry. Therefore, these findings indicate that higher levels of information asymmetry in qualified opinions are generated by those qualifications that include unquantifiable uncertainties and going concern qualifications. Furthermore, we also find that both uncertainties and scope limitations, on the one hand, and going concern qualifications, on the other, present higher information asymmetry than unqualified opinions. Finally, we find that going concern qualifications have a stronger effect on the level of information asymmetry.

These findings are consistent with the hypothesis that audit qualifications are a signal of low accounting quality, thus increasing the uncertainty of earnings and reducing the credibility of firm's financial reporting. Nevertheless, whereas earnings in firms whose qualifications are quantified can be adjusted by market participants and thus are not associated with information asymmetry, the earnings numbers of firms whose qualifications are non-quantified are noisier and more difficult to interpret by market participants and, as a consequence, create information asymmetry in the market. An alternative explanation of these results is that information asymmetry is caused by the underlying economic environment or reporting characteristics of firms, which could also lead to qualified audit opinions, or even that there is an endogenous relation between information asymmetry and audit opinions. However, our 
results are robust to controlling for the financial situation of the firm, the discretionary behavior of managers in financial reporting and the potential endogeneity between audit qualification and information asymmetry.

These findings contribute to the recent research on the economic consequences of audit opinions and reinforce the role played by the audit report in assessing the reliability of financial reporting, confirming that audit opinions affect the market's interpretation of accounting information and that the market is able to discriminate between different types of qualifications. By documenting that the audit opinion is a valuable source of information in the stock market, our results also add to the literature on the effects of accounting quality on information asymmetry.

The results of this study may be specific to the Spanish context and its institutional features, as differences in litigation risk, enforcement and financial reporting quality may affect the associations found. In particular, the lower litigation risk in Spain compared to Anglo-Saxon countries may affect auditor independence and thus reduce the probability of issuing a qualified opinion in Spain when earnings are overstated. Besides, since the quality of financial reporting and investor protection is higher in Anglo-Saxon countries, it is also possible that audit opinions convey more information for investors in countries such as Spain. This implies that the signal to the market from qualified opinions may be stronger in Spain than in Anglo-Saxon countries. If this were true, we would expect to find analogous results in countries with similar or 
lower financial reporting quality and litigation risk than Spain, but the generalization of our results to contexts of higher litigation risk is less certain. We think this could be an interesting extension of this study. Another interesting path for future research on the economic consequences of the audit report would be to examine its connection with the cost of capital. 


\section{References}

Akay, O., H.B. Cyree, M.D. Griffiths, and D.B. Winters, 2012, What does PIN identify? Evidence from the T-bill market, Journal of Financial Markets $15,29-46$.

Ascioglu, A., S.P. Hegde, and J.B. McDermott, 2005, Auditor compensation, disclosure quality, and market liquidity: Evidence from the stock market, Journal of Accounting and Public Policy 24, 325-354.

Bartov, E., F.A. Gul, and J.S.L. Tsui, 2000, Discretionary-accruals models and audit qualifications, Journal of Accounting and Economics 30 (3), 421452.

Begley, K, Ming, B. and Watts, R, 1996, Bankruptcy classification errors in 1980s: an Empirical analysis of Altman's and Ohlson's models, Review of Accounting Studies 1, 267-284.

Bhattacharya, N., H. Desai, and K. Venkataraman, 2013, Does earnings quality affect information asymmetry? Evidence from trading costs, Contemporary Accounting Research 30, 482-516.

Biais, B., P. Hillion, and C. Spatt, 1995, An empirical analysis of the order flow and order book in the Paris Bourse, The Journal of Finance 50, 16551689. 
Blay, A.D., M.A. Geiger, and D.S. North, 2011, The auditor's going-concern opinion as a communication of risk, Auditing: A Journal of Practice \& Theory 30, 77-102.

Brown, S. and S.A. Hillegeist, 2007, How disclosure quality affects the level of information asymmetry, Review of Accounting Studies 12, 443-477.

Butler, M., A.J. Leone, and M. Willenborg, 2004, An empirical analysis of auditor reporting and its association with abnormal accruals, Journal of Accounting and Economics 37, 139-165.

Chen, C., X. Su, and R. Zhao, 2000, An emerging market's reaction to initial modified audit opinions: evidence from the Shanghai stock exchange, Contemporary Accounting Research 17, 429-455.

Chen, P.T., S. He, Z. Ma, and D. Stice, 2014, The information role of audit opinions in debt contracting. Working Paper.

Choi, S.K. and D.C. Jeter, 1992, The effects of qualified audit opinions on earnings response coefficients, Journal of Accounting and Economics 15, 229-247.

Clinch, G., D. Stokes, and T. Zhu, 2012, Audit quality and information asymmetry between traders, Accounting and Finance 52, 743-765.

Danielsen, B.R., R.A. Van Ness, and R.S. Warr, 2007, Audit fees, market microstructure, and firm transparency, Journal of Business Finance \& Accounting 34, 202-221. 
Dechow, P.M.; R.G. Sloan, and A.P. Sweeney, 1995, Detecting earnings management, Accounting Review, 70, 2, 193-225.

Dechow, P., W. Ge, and C. Schrand, 2010, Understanding earnings quality: A review of the proxies, their determinants and their consequences, Journal of Accounting and Economics 50, 344-401.

De las Heras, E., L. Cañibano, and J.A. Moreira, 2012, The impact of the Spanish Financial Act on audit quality, Spanish Journal of Finance and Accounting 41, 521-546.

Diamond, M., 1985, Optimal releases of information by firms, The Journal of Finance 40, 1071-1094.

Diamond, M., and R. Verrecchia, 1991, Disclosure, liquidity and the cost of capital, The Journal of Finance 46, 1325-1359.

Dodd, P., N. Dopuch, R.W. Holthausen, and R.W. Leftwich, 1984, Qualified audit opinions and stock prices, Journal of Accounting and Economics 6, $1-97$.

Dopuch, N., R.W Holthausen, and R.W Leftwich, 1986, Abnormal stock returns associated with media disclosures of "subject to" qualified audit opinions, Journal of Accounting and Economics 8, 91-172.

Dopuch, N., R.W. Holthausen, and R.W. Leftwich, 1987, Predicting audit qualifications with financial and market variables, The Accounting Review $62,431-454$ 
Easley, D., N. Kiefer, and M. O'Hara, 1997, One day in the life of a very common stock, The Review of Financial Studies 10, 805-835.

Easley, D., N. Kiefer, M. O'Hara, and J.B. Paperman, 1996, Liquidity, information, and infrenquentlly traded stocks, The Journal of Finance 51, $1405-1436$.

Easley, D. and M. O’Hara, 1987, Price, trade size and information in security markets, Journal of Financial Economics 19, 69-90.

Easley, D. and M. O'Hara, 1992, Time and the process of security price adjustment, The Journal of Finance 47, 577-604.

Easley, D. and M. O'Hara, 2004, Information and the cost of capital, The Journal of Finance 59, 1553-1583.

Financial Accounting Standards Board (FASB), 2010, Statement of Financial Accounting Concepts No 8. Conceptual Framework for Financial Reporting. FASB, Norwalk, CT.

Firth, M., 1978, Qualified audit reports: their impact on investment decisions, The Accounting Review 53, 599-823.

Fishman, M.J., and K.M. Hagerty, 1989, Disclosure decisions by firms and the competition for price efficiency, The Journal of Finance 44, 633-646.

Glosten, L.R., and P.R. Milgron, 1985, Bid, ask and transaction prices in a specialist market with heterogeneously informed traders, Journal of Financial Economics 14, 71-100. 
Healy, P., A. Hutton, and K. Palepu, 1999, Stock performance and intermediation changes surrounding sustained increases in disclosures, Contemporary Accounting Research 16, 485-520.

Healy, P. and K. Palepu, 2001, Information asymmetry, corporate disclosure, and the capital markets: A review of the empirical disclosure literature, Journal of Accounting and Economics 31, 405-440.

Heflin, F., K.W. Shaw, and J.J. Wild, 2005, Disclosure quality and market liquidity, Contemporary Accounting Research 22, 829-865.

Hope, O-K, W. Thomas, and D. Vyas, 2011, Financial credibility, ownership, and financing constraints in private firms, Journal of International Business Studies 42, 935-957.

Huang, R., and H. Stoll, 1996, Dealer versus auction markets: A paired comparison of execution costs on NASDAQ and NYSE, Journal of Financial Economics 41, 313-357.

Hudaib, M. and T.E. Cooke, 2005, The impact of managing director changes and financial distress on audit qualification and auditor switching, Journal of Business Finance \& Accounting 32, 1703-1739.

International Accountings Standards Board (IASB), 2011, The Conceptual Framework for Financial Reporting, IFRS Fundation. London.

Ireland, J.C., 2003, An empirical investigation of determinants of audit reports in the UK, Journal of Business Finance \& Accounting 30, 975-1015. 
Jones, J.J., 1991, Earnings management during import relief investigations, Journal of Accounting Research, 29, 193-228.

Kausar, A., R. Taffler, and C. Tan, 2009, The going-concern market anomaly, Journal of Accounting Research 47, 213-239.

Kyle, A, 1985, Continuous auctions and insider trading, Econometrica 53, 1315-1335.

Lambert, R.E., C. Leuz, and R.E. Verrechia, 2007, Accounting information, disclosure, and the cost of capital, Journal of Accounting Research 45, $385-420$.

Lambert, R.E., C. Leuz, and R.E. Verrechia, 2012, Information precision, information asymmetry, and the cost of capital, Review of Finance 16, 129.

Leuz, C. and R.E. Verrecchia, 2000, The economic consequences of increased disclosure, Journal of Accounting Research 38, 91-124.

Melumad, N.D. and A. Ziv, 1997, A theoretical examination of the market reaction to auditors' qualifications, Journal of Accounting Research 35, 239-256.

Merton, R.C., 1987, A simple model of capital market equilibrium with incomplete information, The Journal of Finance 42, 483-510. 
Niemi, L., and S. Sundgren, 2012, Are modified audit opinions related to the availability of credit? Evidence from Finnish SMEs, European Accounting Review 21, 767-796.

Ogneva, M. and K.R. Subramanyam, 2007, Does the stock market underreact to going concern opinions? Evidence form the U.S. and Australia, Journal of Accounting and Economics 43, 439-452.

Pucheta Martínez, M.C., A. Vico Martínez, and M.A. García Benau, 2004, Reactions of the Spanish capital market to qualified audit reports, European Accounting Review 13, 689-711.

Soltani, B, 2000, Some empirical evidence to support the relationship between audit reports and stock prices -The French case, International Journal of Auditing 4, 269-291.

Stoll, H.R, 2000, Friction, The Journal of Finance 55, 1479-1514.

Taffler, R., J. Ju, and A. Kausar, 2004, In denial? Stock market underreaction to going-concern audit report disclosures, Journal of Accounting and Economics 38, 263-296.

Welker, M., 1995, Disclosure policy, information asymmetry, and liquidity in equity markets, Contemporary Accounting Research 11, 801-827.

Yang, Y. and S. Zhang, 2012, An improved estimation method and empirical properties of the probability of informed trading, Journal of Banking and Finance 36, 454-467. 
TABLE 1: Sample variables descriptive statistics

\begin{tabular}{|c|c|c|c|c|c|c|}
\hline \multicolumn{7}{|c|}{ Panel A: Continuous variables } \\
\hline & \# obs & Mean & Std. Dev. & Perc 10 & Median & Perc 90 \\
\hline RES & 562 & 0.0066 & 0.0063 & 0.0013 & 0.044 & 0.0152 \\
\hline PI & 562 & 0.0038 & 0.0028 & 0.0011 & 0.003 & 0.0076 \\
\hline PIN & 561 & 0.1894 & 0.0617 & 0.1225 & 0.1797 & 0.2647 \\
\hline ASY $f$ & 561 & 0.0000 & 1.0000 & -1.0519 & -0.2578 & 1.4942 \\
\hline Size & 562 & 14.2206 & 1.7216 & 12.0982 & 14.1309 & 16.6347 \\
\hline Turnover & 562 & -6.2655 & 1.0508 & -7.5443 & -6.2707 & -5.1237 \\
\hline Volat & 562 & 0.0366 & 0.0514 & 0.0094 & 0.0233 & 0.0766 \\
\hline Zscore & 562 & 0.4968 & 0.5420 & 0.2142 & 0.4232 & 0.8130 \\
\hline \multicolumn{7}{|c|}{ Panel B: Dummy variables } \\
\hline & \# obs & & 0 & & 1 & \\
\hline \multirow{4}{*}{$\begin{array}{l}\text { QAO } \\
\text { BigN }\end{array}$} & 562 & & $491(87.37 \%)$ & \multicolumn{3}{|c|}{$71(12.63 \%)$} \\
\hline & 562 & & $33(5.87 \%)$ & \multicolumn{3}{|c|}{$529(94.13 \%)$} \\
\hline & \# obs & \multicolumn{2}{|r|}{ Quantified } & \multicolumn{3}{|c|}{ Non-Quantified } \\
\hline & & \multirow{2}{*}{\multicolumn{2}{|c|}{$19(26.76 \%)$}} & & ertainties & Gconcern \\
\hline Qualified opinions & 71 & & & & $(46.48 \%)$ & $19(26.76 \%)$ \\
\hline
\end{tabular}

The table shows some descriptive statistics for our final sample of 562 firm-years. Panel A reports the descriptive statistics for continuous variables used in the study. RES is the relative effective spread (i.e., twice the absolute value of the difference between marginal trade price and the bid-ask midpoint, divided by the bid-ask midpoint). PI is the price impact measure proposed by Huang and Stoll (1996) using a 30minute interval. PIN is the Probability of Informed Trading based on the Easley et al. (1996) model. ASYf is the composite index of information asymmetry based on the former measures of information asymmetry (RES, PI, and PIN). Size is the logarithm of the total asset at the end of the fiscal year. Turnover is the logarithm of the trading volume scaled by market value of the firm's equity at the end of the fiscal year. Volat is a proxy for stock return volatility calculated as the daily squared close-to-open mid-quote return (x100); Zscore is the re-estimated Altman Z-score by Begley et al. (1996). Panel B reports the frequencies of dummy variables used in the study. BigN is a proxy for audit quality, which takes value 1 if the firm is audited by a Big $n$ and 0 otherwise. $Q A O$ takes the value 1 in the case of qualified opinion, and 0 in the case of unqualified opinion. Quantified takes the value 1 in the case of quantified audit reports, and 0 in the case of unqualified audit reports. Non-quantified takes the value 1 in the case of non-quantified audit opinions (going concern, scope limitations and uncertainties), and 0 in the case of unqualified audit opinions. Uncertainties takes the value 1 in the case of uncertainties and scope limitations, and 0 in the case of unqualified audit opinions. Gconcern takes the value 1 in the case of going concern audit reports, and 0 in the case of unqualified audit opinions. 
TABLE 2: Audit opinions statistics

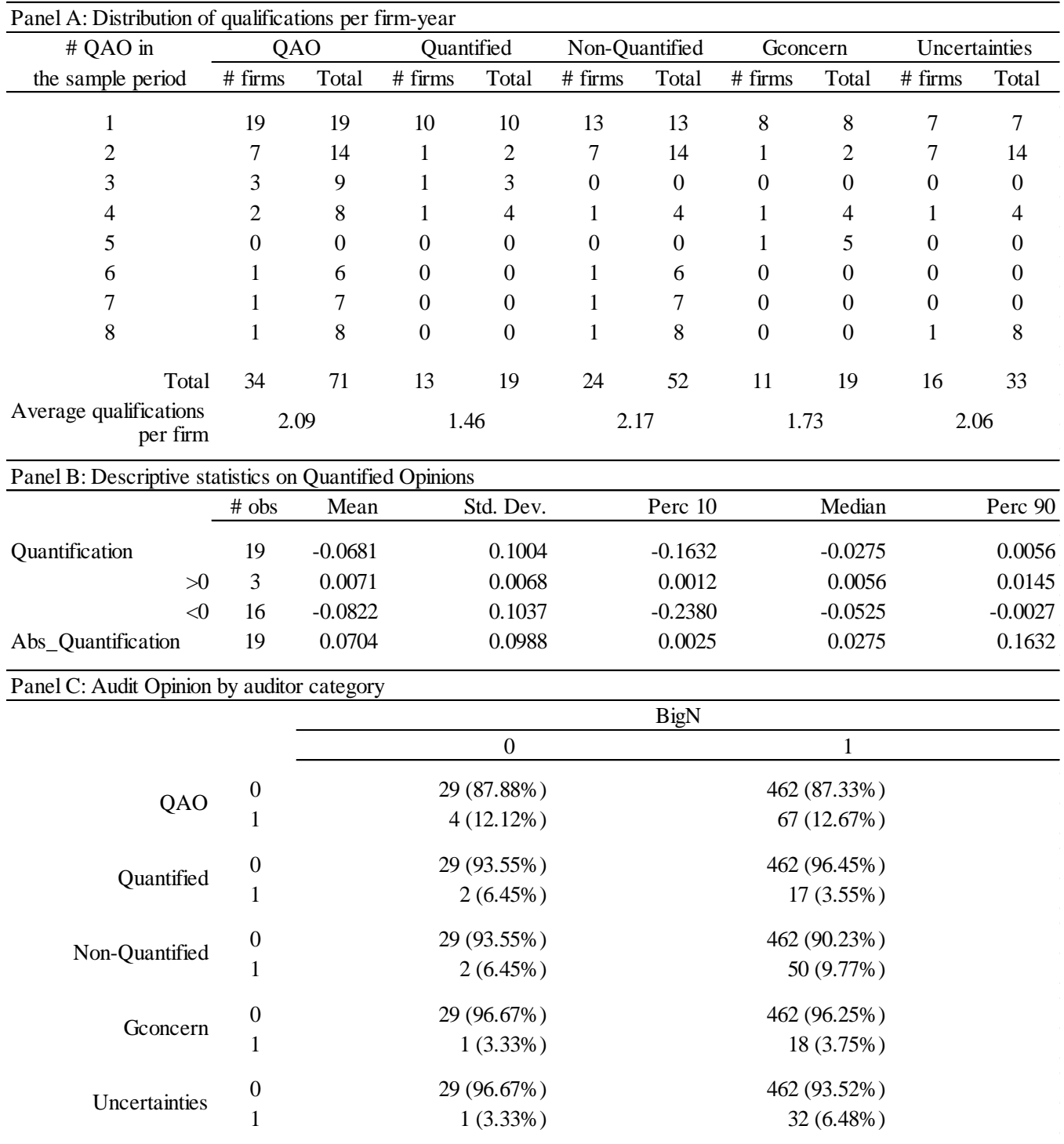

The Table reports some descriptive statistics for audit opinions in our sample. Panel A presents the distribution of qualifications in the sample. For each audit qualification category two columns are reported: the first column indicates the number of firms receiving a certain number of qualifications in our eight-year sample period (from a minimum of 1 to a maximum of 8) and the second column shows the total number of qualifications. Panel B presents descriptive statistics of quantified opinions. Quantification is the relative value over total assets of the income effect of quantified opinions. Abs_Quantification is the absolute value of Quantification. Finally, Panel C reports the distribution of audit opinions by auditor category (Big $n$ and non-Big $n$ ). 
TABLE 3: Correlation matrix

\begin{tabular}{|c|c|c|c|c|c|c|c|c|}
\hline & RES & PI & PIN & $\mathrm{ASY} f$ & Size & Turnover & Volat & Zscore \\
\hline RES & 1 & & & & & & & \\
\hline PI & $0.928 * * *$ & 1 & & & & & & \\
\hline PIN & $0.577 * * *$ & $0.511 * * *$ & 1 & & & & & \\
\hline ASY $f$ & $0.957 * * *$ & $0.936 * * *$ & $0.756 * * *$ & 1 & & & & \\
\hline Size & $-0.620 * * *$ & $-0.605 * * *$ & $-0.562 * * *$ & $-0.670 * * *$ & 1 & & & \\
\hline Turnover & $-0.306 * * *$ & $-0.147 * * *$ & $-0.535 * * *$ & $-0.352 * * *$ & $0.179 * * *$ & 1 & & \\
\hline Volat & $0.286 * * *$ & $0.419 * * *$ & 0.014 & $0.286 * * *$ & $-0.069 *$ & $0.259 * * *$ & 1 & \\
\hline Zscore & -0.034 & -0.028 & 0.042 & -0.012 & $-0.100 * *$ & $-0.115 * * *$ & -0.069 & 1 \\
\hline
\end{tabular}

The table reports the correlation coefficient between the variables used in the study. RES is the relative effective spread. PI is price impact measure proposed by Huang and Stoll (1996) using a 30-minute interval. PIN is the Probability of Informed Trading based on the Easley et al. (1996) model. ASYf is the composite index of information asymmetry based on RES, PI, and PIN. Size is the logarithm of the total asset at the end of the fiscal year. Turnover is the logarithm of the trading volume scaled by the market value of the firm's equity at the end of the fiscal year. Volat is a proxy for stock return volatility calculated as the daily squared close-to-open mid-quote return (x100). Zscore is the re-estimated Altman Z-score by Begley et al. (1996). *,**, and *** represent significance levels at two-tail tests of 0.10, 0.05, and 0.01 , respectively. 
TABLE 4: Univariate analysis of the relationship between audit opinions and audit quality with information asymmetry

\begin{tabular}{|c|c|c|c|c|c|c|}
\hline \multicolumn{7}{|c|}{ Panel A: Mean differences by audit opinion } \\
\hline & $\mathrm{QAO}$ & \#obs & Mean & Std.dev. & t-test & z-statistic \\
\hline \multirow{2}{*}{ RES } & 0 & 391 & 0.0058 & 0.0060 & \multirow{2}{*}{$-3.417 * * *$} & \multirow{2}{*}{$-3.854 * * *$} \\
\hline & 1 & 52 & 0.0098 & 0.0081 & & \\
\hline \multirow{2}{*}{ PI } & 0 & 391 & 0.0034 & 0.0027 & \multirow{2}{*}{$-3.444 * * *$} & \multirow{2}{*}{$-3.858 * * *$} \\
\hline & 1 & 52 & 0.0052 & 0.0036 & & \\
\hline \multirow{2}{*}{ PIN } & 0 & 390 & 0.1864 & 0.0628 & \multirow{2}{*}{-1.460} & \multirow{2}{*}{$-2.300 * *$} \\
\hline & 1 & 52 & 0.1996 & 0.0512 & & \\
\hline \multirow{2}{*}{ ASY $f$} & 0 & 390 & -0.1219 & 0.9739 & \multirow{2}{*}{$-3.906 * * *$} & \multirow{2}{*}{$-3.860 * * *$} \\
\hline & 1 & 52 & 0.4506 & 1.1262 & & \\
\hline
\end{tabular}

Panel B: Mean differences by audit quality

\begin{tabular}{ccccccl} 
& BigN & \#obs & Mean & Std.dev. & t-test & z-statistic \\
\cline { 2 - 7 } RES & 0 & 27 & 0.0097 & 0.0056 & $2.829 * * *$ & $4.368 * * *$ \\
& 1 & 416 & 0.0061 & 0.0064 & & \\
& & & & & & \\
PI & 0 & 27 & 0.0049 & 0.0021 & $2.500 * * *$ & $3.943 * * *$ \\
& 1 & 416 & 0.0035 & 0.0029 & & \\
& & & & & & \\
PIN & 0 & 27 & 0.2016 & 0.0313 & 2.157 & $2.187 * *$ \\
& 1 & 415 & 0.1870 & 0.0631 & & \\
& & & & & & \\
ASYf & 0 & 27 & 0.4156 & 0.6271 & $3.831 * * *$ & $3.843 * * *$
\end{tabular}

The table presents the information asymmetry proxies by audit opinion groups (Panel A) and audit quality groups (Panel B). QAO takes the value 1 in the case of qualified opinion, and zero in the case of unqualified opinion. $B i g N$ is a proxy for audit quality, which takes value 1 if the firm is audited by a Big $n$ and 0 otherwise. RES is the relative effective spread. $P I$ is price impact measure proposed by Huang and Stoll (1996). PIN is the Probability of Informed Trading based on the Easley et al. (1996) model. ASYf is the composite index of information asymmetry based on RES, PI, and PIN. The $t$-test and Mann-Whitney (z-statistic) test are used to test the null hypothesis of no significant differences in each information asymmetry proxy between two groups. $*$, **, and *** represent significance levels at two-tail tests of $0.10,0.05$, and 0.01 , respectively. 
TABLE 5: Regressions estimates for information asymmetry on audit opinions

\begin{tabular}{|c|c|c|c|c|}
\hline & $R E S$ & $P I$ & $P I N$ & $A S Y f$ \\
\hline QAO & $\begin{array}{l}0.0024 * * \\
(2.21)\end{array}$ & $\begin{array}{l}0.001 * * \\
(2.18)\end{array}$ & $\begin{array}{r}0.0064 \\
(0.89)\end{array}$ & $\begin{array}{c}0.3133 * * \\
(2.34)\end{array}$ \\
\hline Size & $\begin{array}{l}-0.0022 * * * \\
(-6.08)\end{array}$ & $\begin{array}{l}-0.0010 * * * \\
(-7.60)\end{array}$ & $\begin{array}{l}-0.0166 * * * \\
(-8.26)\end{array}$ & $\begin{array}{l}-0.3651 * * * \\
(-8.17)\end{array}$ \\
\hline Turnover & $\begin{array}{l}-0.0017 * * * \\
(-2.66)\end{array}$ & $\begin{array}{l}-0.0004 * \\
(-1.98)\end{array}$ & $\begin{array}{l}-0.0279 * * * \\
(-6.77)\end{array}$ & $\begin{array}{c}-0.3171 * * * \\
(-3.64)\end{array}$ \\
\hline Volat & $\begin{array}{c}0.0253 * * * \\
(3.82)\end{array}$ & $\begin{array}{l}0.0140 * * \\
(3.67)\end{array}$ & $\begin{array}{r}0.0783 \\
(1.28)\end{array}$ & $\begin{array}{l}4.0100 * * * \\
(3.32)\end{array}$ \\
\hline $\mathrm{BigN}$ & $\begin{array}{l}-0.0023 * \\
(-1.77)\end{array}$ & $\begin{array}{l}-0.0007 * \\
(-1.70)\end{array}$ & $\begin{array}{r}-0.0003 \\
(-0.03)\end{array}$ & $\begin{array}{l}-0.2525 * \\
(-1.66)\end{array}$ \\
\hline Zscore & $\begin{array}{l}-0.0014 * * \\
(-2.20)\end{array}$ & $\begin{array}{l}-0.0006 * * \\
(-2.31)\end{array}$ & $\begin{array}{l}-0.0046 * * \\
(-2.11)\end{array}$ & $\begin{array}{l}-0.1949 * * \\
(-2.49)\end{array}$ \\
\hline Intercept & $\begin{array}{l}0.0334 * * * \\
(3.61)\end{array}$ & $\begin{array}{l}0.0175 * * * \\
(5.10)\end{array}$ & $\begin{array}{l}0.2423 * * * \\
(5.17)\end{array}$ & $\begin{array}{l}3.9277 * * * \\
(3.46)\end{array}$ \\
\hline Year dummies & Yes & Yes & Yes & Yes \\
\hline Industry dummies & Yes & Yes & Yes & Yes \\
\hline $\mathrm{R}^{2}$ & 0.5994 & 0.6301 & 0.5759 & 0.6846 \\
\hline \#obs & 443 & 443 & 442 & 442 \\
\hline
\end{tabular}

The table presents the regression coefficients for information asymmetry proxies on audit opinions and control variables:

$$
A S Y_{i, t}=\beta_{0}+\beta_{1} Q A O_{i, t-1}+\beta_{2} \text { Size }_{i, t}+\beta_{3} \text { Turnover }_{i, t}+\beta_{4} \text { Volat }_{i, t}+\beta_{5} \text { BigN }_{i, t-1}+\beta_{6} \text { Zscore }_{i, t}+\sum_{t} \beta_{t} \text { Year }+\sum_{j} \beta_{j} \text { Ind }+\varepsilon_{i, t}
$$

The information asymmetry proxies are: RES, the relative effective spread; $P I$, the price impact measure proposed by Huang and Stoll (1996). PIN is the Probability of Informed Trading based on the Easley et al. (1996) model. ASYf is the composite index of information asymmetry based on RES, PI, and PIN. The independent variables are: $Q A O$, a dummy variable that takes the value 1 in the case of qualified opinion, and 0 in the case of unqualified opinion. Size is the logarithm of the total asset at the end of the fiscal year. Turnover is the logarithm of the trading volume scaled by the market value of the firm's equity at the end of the fiscal year. Volat is a proxy for stock return volatility calculated as the daily squared closeto-open mid-quote return (x100). BigN is a proxy for audit quality, which takes value 1 if the firm is audited by a Big $n$ and 0 otherwise. Zscore is the re-estimated Altman Z-score by Begley et al. (1996). Robust t-statistics clustered at the firm level in parentheses. *,**, and *** represent significance levels at two-tail tests of $0.10,0.05$, and 0.01 , respectively. 
TABLE 6: Regressions estimates for Information asymmetry index on different types of qualified audit opinions.

Quantified

Non-Quantified

Gconcern

Uncertainties

0.1213

(0.54)

$0.4405 * * *$

(2.88)

Size

Turnover

Volat

$\mathrm{BigN}$

Zscore

Intercept

Year dummies

Industry dummies

$\mathrm{R}^{2}$

\#obs
$-0.3508 * * *$

$(-7.25)$

$-0.3333 * * *$

4.2078 ***

$-0.2868 *$

$(-1.78)$

$-0.1573 * *$

$(-2.30)$

3.0710 **

(2.60)

Yes

Yes

0.6708

408
$1.0200 * * *$

(2.84)

$0.2787 * *$

(2.04)

$-0.3359 * * *$

$(-7.64)$

$(-8.03)$

$-0.3472 * * *$

$-0.3565 * * *$

$-0.3318 * * *$

$(-7.16)$

$-0.3395 * * *$

(-3.98)

$(-3.75)$

$(-3.63)$

$3.9352 * * *$

$3.8524 * * *$

3.6650 ***

(3.40)

(3.40)

-0.3129 *

$-0.2818 *$

$-0.2964 *$

$(-1.79)$

$(-1.66)$

$(-1.66)$

$-0.1542 * *$

$(-2.51)$

$-0.1806 * *$

$(-2.40)$

$(-2.55)$

2.6753 **

$3.0524 * * *$

2.9892 **

(2.35)

(2.71)

(2.47)

Yes

Yes

Yes

Yes

Yes

0.6939

0.6909

0.6824

398

416

The table presents the regression coefficients for information asymmetry composite index (ASYf) on different types of audit qualifications $(Q A O)$ and control variables:

$$
A S Y f_{i, t}=\beta_{0}+\beta_{1} Q A O_{i, t-1}+\beta_{2} \text { Size }_{i, t}+\beta_{3} \text { Turnover }_{i, t}+\beta_{4} \text { Volat }_{i, t}+\beta_{5} \text { BigN }_{i, t-1}+\beta_{6} \text { Zscore }_{i, t}+\sum_{t} \beta_{t} \text { Year }+\sum_{j} \beta_{j} \text { Ind }+\varepsilon_{i, t}
$$

The independent variable $Q A O$ is Quantified in (1), a dummy variable that takes the value 1 in the case of quantified audit opinions, and 0 in the case of unqualified audit opinions. $Q A O$ is Non-quantified in (2), a dummy variable that takes the value 1 in the case of non-quantified audit opinions and 0 in the case of unqualified audit opinions. $Q A O$ is Uncertainties in (3), a dummy variable that takes the value 1 in the case of uncertainties and scope limitations, and 0 in the case of unqualified audit opinions. Finally, $Q A O$ is Gconcern in (4), a dummy variable that takes the value 1 in the case of going concern audit reports, and 0 in the case of unqualified audit opinions. Control variables are: Size, the logarithm of the total asset at the end of the fiscal year; Turnover, the logarithm of the trading volume scaled by the market value of the firm's equity at the end of the fiscal year; Volat, a proxy for stock return volatility calculated as the daily squared close-to-open mid-quote return (x100). BigN is a proxy for audit quality, which takes value 1 if the firm is audited by a Big $\mathrm{n}$ and 0 otherwise. Zscore is the re-estimated Altman Z-score by Begley et al. (1996). Robust t-statistics clustered at the firm level in parentheses.*, **, and *** represent significance levels at two-tail tests of $0.10,0.05$, and 0.01 , respectively. 
TABLE 7: Regressions estimates for information asymmetry index on different types of qualified audit opinions controlling for discretionary accruals.

\begin{tabular}{|c|c|c|c|c|c|}
\hline & $(1)$ & $(2)$ & (3) & (4) & (5) \\
\hline QAO & $\begin{array}{l}0.2878 * * \\
(2.18)\end{array}$ & & & & \\
\hline Quantified & & $\begin{array}{r}0.1021 \\
(0.47)\end{array}$ & & & \\
\hline Non-Quantified & & & $\begin{array}{l}0.4118 * * * \\
(2.71)\end{array}$ & & \\
\hline Gconcern & & & & $\begin{array}{l}0.9338 * * * \\
(2.55)\end{array}$ & \\
\hline Uncertainties & & & & & $\begin{array}{c}0.2667 * \\
(1.92)\end{array}$ \\
\hline Size & $\begin{array}{l}-0.3757 * * * \\
(-8.12)\end{array}$ & $\begin{array}{l}-0.3611 * * * \\
(-7.23)\end{array}$ & $\begin{array}{l}-0.3610 * * * \\
(-7.92)\end{array}$ & $\begin{array}{l}-0.3579 * * * \\
(-7.06)\end{array}$ & $\begin{array}{l}-0.3457 * * * \\
(-7.50)\end{array}$ \\
\hline Turnover & $\begin{array}{l}-0.3244 * * * \\
(-3.79)\end{array}$ & $\begin{array}{l}-0.3376 * * * \\
(-3.74)\end{array}$ & $\begin{array}{l}-0.3397 * * * \\
(-3.90)\end{array}$ & $\begin{array}{l}-0.3452 * * * \\
(-3.74)\end{array}$ & $\begin{array}{l}-0.3610 * * * \\
(-4.09)\end{array}$ \\
\hline Volat & $\begin{array}{l}3.7883 * * * \\
(3.30)\end{array}$ & $\begin{array}{l}4.0728 * * * \\
(3.24)\end{array}$ & $\begin{array}{l}3.6370 * * * \\
(3.38)\end{array}$ & $\begin{array}{l}3.4969 * * * \\
(3.37)\end{array}$ & $\begin{array}{l}3.8029 * * * \\
(3.45)\end{array}$ \\
\hline $\mathrm{BigN}$ & $\begin{array}{r}-0.2305 \\
(-1.50)\end{array}$ & $\begin{array}{r}-0.2676 \\
(-1.65)\end{array}$ & $\begin{array}{r}-0.2561 \\
(-1.48)\end{array}$ & $\begin{array}{r}-0.2691 \\
(-1.47)\end{array}$ & $\begin{array}{r}-0.2942 \\
(-1.66)\end{array}$ \\
\hline Zscore & $\begin{array}{l}-0.3655 * * \\
(-2.46)\end{array}$ & $\begin{array}{l}-0.3105 * * \\
(-2.20)\end{array}$ & $\begin{array}{l}-0.3618 * * \\
(-2.46)\end{array}$ & $\begin{array}{l}-0.3377 * * \\
(-2.36)\end{array}$ & $\begin{array}{l}-0.2944 * * \\
(-2.20)\end{array}$ \\
\hline DiscAcc & $\begin{array}{r}-0.4445 \\
(-0.84)\end{array}$ & $\begin{array}{r}-0.4924 \\
(-0.90)\end{array}$ & $\begin{array}{r}-0.3267 \\
(-0.60)\end{array}$ & $\begin{array}{r}-0.2838 \\
(-0.50)\end{array}$ & $\begin{array}{r}-0.4129 \\
(-0.76)\end{array}$ \\
\hline Intercept & $\begin{array}{l}4.1857 * * * \\
(3.54)\end{array}$ & $\begin{array}{l}3.1961 * * \\
(2.66)\end{array}$ & $\begin{array}{l}3.2625 * * \\
(2.78)\end{array}$ & $\begin{array}{l}3.7985 * * \\
(2.90)\end{array}$ & $\begin{array}{c}2.8843 * * \\
(2.42)\end{array}$ \\
\hline Year dummies & Yes & Yes & Yes & Yes & Yes \\
\hline Industry dummies & Yes & Yes & Yes & Yes & Yes \\
\hline $\mathrm{R}^{2}$ & 0.6903 & 0.6760 & 0.6962 & 0.6872 & 0.6978 \\
\hline \#obs & 438 & 404 & 420 & 394 & 412 \\
\hline
\end{tabular}

The table presents the regression coefficients for information asymmetry composite index (ASYf) on different types of audit qualifications and control variables:

$A S Y f_{i, t}=\beta_{0}+\beta_{1} Q_{A O} O_{i, t-1}+\beta_{2}$ Size $_{i, t}+\beta_{3}$ Turnover $_{i, t}+\beta_{4}$ Volat $_{i, t}+\beta_{5}$ BigN $_{i, t-1}+\beta_{6}$ Zscore $_{i, t}+\beta_{7}$ DiscAcc $_{i, t}+\sum_{t} \beta_{t}$ Year $+\sum_{j} \beta_{j}$ Ind $_{j}+\varepsilon_{i, t}$

The independent variable $Q A O$ in (1) is a dummy variable that takes the value 1 in the case of qualified opinion, and 0 in the case of unqualified opinion. $Q A O$ is Quantified in (2), a dummy variable that takes the value 1 in the case of quantified audit opinions, and 0 in the case of unqualified audit opinions. $Q A O$ is Non-quantified in (3), a dummy variable that takes the value 1 in the case of non-quantified audit opinions and 0 in the case of unqualified audit opinions. $Q A O$ is Uncertainties in (4), a dummy variable that takes the value 1 in the case of uncertainties and scope limitations, and 0 in the case of unqualified audit opinions. Finally, $Q A O$ is Gconcern in (5), a dummy variable that takes the value 1 in the case of going concern audit reports, and 0 in the case of unqualified audit opinions. Control variables are: Size, the logarithm of the total asset at the end of the fiscal year; Turnover, the logarithm of the trading volume scaled by the market value of the firm's equity at the end of the fiscal year; Volat, a proxy for stock return volatility calculated as the daily squared close-to-open mid-quote return (x100). Zscore is the re-estimated Altman Z-score by Begley et al. (1996). DiscAcc is the absolute value of discretionary accruals estimated by the Jones (1991) model modified by Dechow et al. (1995). Robust t-statistics clustered at the firm level in parentheses.*,**, and $* * *$ represent significance levels at two-tail tests of $0.10,0.05$, and 0.01 , respectively. 
TABLE 8: Regressions estimates for Information asymmetry index on different types of qualified audit opinions from Big $\boldsymbol{n}$ auditors

\begin{tabular}{|c|c|c|c|c|c|}
\hline & $(1)$ & (2) & (3) & (4) & (5) \\
\hline QAO & $\begin{array}{l}0.3134 * * \\
(2.24)\end{array}$ & & & & \\
\hline Quantified & & $\begin{array}{r}0.0452 \\
(0.27)\end{array}$ & & & \\
\hline Non-Quantified & & & $\begin{array}{l}0.4604 \text { *** } \\
(2.75)\end{array}$ & & \\
\hline Gconcern & & & & $\begin{array}{l}1.0380 * * * \\
(2.80)\end{array}$ & \\
\hline Uncertainties & & & & & $\begin{array}{c}0.2766 * \\
(1.85)\end{array}$ \\
\hline Size & $\begin{array}{l}-0.3628 * * * \\
(-7.98)\end{array}$ & $\begin{array}{l}-0.3453 * * * \\
(-7.03)\end{array}$ & $\begin{array}{l}-0.3509 * * * \\
(-7.89)\end{array}$ & $\begin{array}{l}-0.3492 * * * \\
(-7.01)\end{array}$ & $\begin{array}{l}-0.3370 \text { *** } \\
(-7.43)\end{array}$ \\
\hline Turnover & $\begin{array}{l}-0.3356 * * * \\
(-3.60)\end{array}$ & $\begin{array}{l}-0.3568 \text { *** } \\
(-3.62)\end{array}$ & $\begin{array}{l}-0.3434 \text { *** } \\
(-3.64)\end{array}$ & $\begin{array}{l}-0.3534 \text { *** } \\
(-3.54)\end{array}$ & $\begin{array}{l}-0.3716 \text { *** } \\
(-3.86)\end{array}$ \\
\hline Volat & $\begin{array}{l}3.9141 \text { *** } \\
(3.38)\end{array}$ & $\begin{array}{l}4.0390 \text { *** } \\
(3.38)\end{array}$ & $\begin{array}{l}3.7661 \text { *** } \\
(3.47)\end{array}$ & $\begin{array}{l}3.5623 \text { *** } \\
(3.48)\end{array}$ & $\begin{array}{l}3.8229 * * * \\
(3.55)\end{array}$ \\
\hline Zscore & $\begin{array}{l}-0.1919 * * \\
(-2.45)\end{array}$ & $\begin{array}{l}-0.1525 * * \\
(-2.24)\end{array}$ & $\begin{array}{l}-0.1885 * * \\
(-2.46)\end{array}$ & $\begin{array}{l}-0.1755 \text { ** } \\
(-2.50)\end{array}$ & $\begin{array}{l}-0.1494 * * \\
(-2.34)\end{array}$ \\
\hline Intercept & $\begin{array}{l}3.5178 * * * \\
(3.05)\end{array}$ & $\begin{array}{l}3.0112 * * \\
(2.43)\end{array}$ & $\begin{array}{l}3.2624 \text { *** } \\
(2.81)\end{array}$ & $\begin{array}{l}3.1928 * * \\
(2.55)\end{array}$ & $\begin{array}{c}2.0835 * \\
(1.81)\end{array}$ \\
\hline Year dummies & Yes & Yes & Yes & Yes & Yes \\
\hline Industry dummies & Yes & Yes & Yes & Yes & Yes \\
\hline $\mathrm{R}^{2}$ & 0.6927 & 0.6810 & 0.6969 & 0.6884 & 0.7006 \\
\hline \#obs & 414 & 383 & 399 & 376 & 391 \\
\hline
\end{tabular}

The table presents the regression coefficients for information asymmetry composite index (ASYf) on different types of audit qualifications from Big $\mathrm{n}$ auditors and control variables:

$$
A_{S Y f_{i, t}}=\beta_{0}+\beta_{1} \text { AAO }_{i, t-1}+\beta_{2} \text { Size }_{i, t}+\beta_{3} \text { Turnover }_{i, t}+\beta_{4} \text { Volat }_{i, t}+\beta_{5} \text { BigN }_{i, t-1}+\beta_{6} \text { Zscore }_{i, t}+\sum_{t} \beta_{t} \text { Year }+\sum_{j} \beta_{j} \text { Ind }+\varepsilon_{i, t}
$$

The independent variable $Q A O$ in (1) is a dummy variable that takes the value 1 in the case of qualified opinion, and 0 in the case of unqualified opinion. $Q A O$ is Quantified in (2), a dummy variable that takes the value 1 in the case of quantified audit opinions, and 0 in the case of unqualified audit opinions. $Q A O$ is Non-quantified in (3), a dummy variable that takes the value 1 in the case of non-quantified audit opinions and 0 in the case of unqualified audit opinions. $Q A O$ is Uncertainties in (4), a dummy variable that takes the value 1 in the case of uncertainties and scope limitations, and 0 in the case of unqualified audit opinions. Finally, $Q A O$ is Gconcern in (5), a dummy variable that takes the value 1 in the case of going concern audit reports, and 0 in the case of unqualified audit opinions. Control variables are: Size, the logarithm of the total asset at the end of the fiscal year; Turnover, the logarithm of the trading volume scaled by the market value of the firm's equity at the end of the fiscal year; Volat, a proxy for stock return volatility calculated as the daily squared close-to-open mid-quote return (x100). Zscore is the re-estimated Altman Z-score by Begley et al. (1996). Robust t-statistics clustered at the firm level in parentheses.*,**, and $* * *$ represent significance levels at two-tail tests of $0.10,0.05$, and 0.01 , respectively. 
TABLE 9: Two-stage probit regressions estimates on the information asymmetry and audit opinions relationship.

\begin{tabular}{|c|c|c|c|c|}
\hline & $\mathrm{P}(\mathrm{QAO})$ & $\mathrm{P}(\mathrm{QAO})$ & $\mathrm{ASY} f$ & $\mathrm{ASY} f$ \\
\hline Est (QAO) & & & $\begin{array}{l}1.6271 * * * \\
(4.78)\end{array}$ & $\begin{array}{l}1.6343 \text { *** } \\
(4.90)\end{array}$ \\
\hline Size & $\begin{array}{l}-0.2132 \text { ** } \\
(-2.12)\end{array}$ & $\begin{array}{l}-0.2248 \text { ** } \\
(-2.20)\end{array}$ & $\begin{array}{l}-0.3197 * * * \\
(-6.35)\end{array}$ & $\begin{array}{l}-0.3145 \text { *** } \\
(-6.20)\end{array}$ \\
\hline Turnover & & & $\begin{array}{l}-0.3389 * * * \\
(-4.25)\end{array}$ & $\begin{array}{l}-0.3592 \text { *** } \\
(-4.21)\end{array}$ \\
\hline Volat & & & $\begin{array}{l}3.8312 * * * \\
(3.59)\end{array}$ & $\begin{array}{l}3.7250 \text { *** } \\
(3.67)\end{array}$ \\
\hline $\mathrm{BigN}$ & $\begin{array}{r}0.4121 \\
(0.96)\end{array}$ & & $\begin{array}{c}-0.2549 * \\
(-1.85)\end{array}$ & \\
\hline Zscore & $\begin{array}{l}-2.0408 * * * \\
(-3.10)\end{array}$ & $\begin{array}{l}-2.0060 * * * \\
(-2.98)\end{array}$ & $\begin{array}{l}-0.2381 * * \\
(-2.23)\end{array}$ & $\begin{array}{l}-0.2356 * * \\
(-2.12)\end{array}$ \\
\hline DiscAcc & $\begin{array}{l}2.5894 * * \\
(2.55)\end{array}$ & $\begin{array}{l}2.4013 \text { ** } \\
(2.26)\end{array}$ & & \\
\hline ASY & $\begin{array}{r}0.1834 \\
(1.14)\end{array}$ & $\begin{array}{r}0.1643 \\
(1.00)\end{array}$ & & \\
\hline Intercept & $\begin{array}{c}2.9278 * \\
(1.80)\end{array}$ & $\begin{array}{l}3.5476 * * \\
(2.11)\end{array}$ & $\begin{array}{l}3.0698 * * \\
(2.49)\end{array}$ & $\begin{array}{c}1.9065 * \\
(1.62)\end{array}$ \\
\hline Year dummies & Yes & Yes & Yes & Yes \\
\hline Industry dummie & Yes & Yes & Yes & Yes \\
\hline $\mathrm{R}^{2}$ & 0.2391 & 0.241 & 0.7083 & 0.7158 \\
\hline \#obs & 556 & 523 & 439 & 411 \\
\hline
\end{tabular}

The table presents in columns 1 and 2 the following first-stage probit regressions of the audit opinion on information asymmetry:

$$
\begin{gathered}
P(Q A O)_{i, t}=\beta_{0}+\beta_{1} \text { Size }_{i, t}+\beta_{2} \text { BigN }_{i, t}+\beta_{3} \text { Zscore }_{i, t}+\beta_{4} \operatorname{DiscAcc}_{i, t}+\beta_{5} A S Y f_{i, t}+\sum_{t} \beta_{t} \text { Year }+\sum_{j} \beta_{j} \text { Ind }+\varepsilon_{i, t} \\
P(Q A O)_{i, t}=\beta_{0}+\beta_{1} \text { Size }_{i, t}+\beta_{2} \text { Zscore }_{i, t}+\beta_{3} \text { DiscAcc }_{i, t}+\beta_{4} A S Y f_{i, t}+\sum_{t} \beta_{t} \text { Year }+\sum_{j} \beta_{j} \operatorname{Ind}+\varepsilon_{i, t}
\end{gathered}
$$

In columns 3 and 4 the following second-stage regressions are estimated:

$$
\begin{aligned}
& A S Y f_{i, t}=\beta_{0}+\beta_{1} \text { Est }_{(Q A O)_{i, t-1}}+\beta_{2} \text { Size }_{i, t}+\beta_{3} \text { Turnover }_{i, t}+\beta_{4} \text { Volat }_{i, t}+\beta_{5} \text { BigN }_{i, t-1}+\beta_{6} \text { Zscore }_{i, t}+\sum_{t} \beta_{t} \text { Year }+\sum_{j} \beta_{j} \text { Ind }+\varepsilon_{i, t} \\
& A S Y f_{i, t}=\beta_{0}+\beta_{1} \text { Est }_{(Q A O)_{i, t-1}}+\beta_{2} \text { Size }_{i, t}+\beta_{3} \text { Turnover }_{i, t}+\beta_{4} \text { Volat }_{i, t}+\beta_{5} \text { Zscore }_{i, t}+\sum_{t} \beta_{t} \text { Year }+\sum_{j} \beta_{j} \text { Ind }+\varepsilon_{i, t}
\end{aligned}
$$

$A S Y f$ is the composite index of information asymmetry based on RES, PI, and PIN measures. QAO is a dummy variable that takes the value 1 in the case of qualified opinion, and zero in the case of unqualified opinion. Size is the logarithm of the total asset at the end of the fiscal year. Turnover is the logarithm of the trading volume scaled by the market value of the firm's equity at the end of the fiscal year. Volat is a proxy for stock return volatility calculated as the daily squared close-to-open mid-quote return (x100). $B i g N$ is a proxy for audit quality, which takes value 1 if the firm is audited by a $\operatorname{Big} n$ and 0 otherwise. Zscore is the re-estimated Altman Z-score by Begley et al. (1996). DiscAcc is the absolute value of discretionary accruals estimated by the Jones (1991) model modified by Dechow et al. (1995). Robust tstatistics clustered at the firm level in parentheses.*, **, and *** represent significance levels at two-tail tests of $0.10,0.05$, and 0.01 , respectively. 